This pdf of your paper in TRAC 2013 belongs to the publishers Oxbow Books and it is their copyright.

As author you are licenced to make up to 50 offprints from it, but beyond that you may not publish it on the World Wide Web until three years from publication (March 2017), unless the site is a limited access intranet (password protected). If you have queries about this please contact the editorial department at Oxbow Books (editorial@oxbowbooks.com). 


\section{An offprint from TRAC 2013}

Proceedings of the Twenty-Third Annual

\section{THEORETICAL ROMAN ARCHAEOLOGY CONFERENCE}

which took place at

King's College London

4-6 April 2013

edited by

Hannah Platts, John Pearce, Caroline Barron, Jason Lundock, Justin Yoo

Paperback Edition: ISBN 978-1-78297-690-5

Digital Edition: ISBN 978-1-78297-691-2

(c) Oxbow Books 2014

Oxford and Philadelphia

www.oxbowbooks.com 
Published in the United Kingdom in 2014 by

OXBOW BOOKS

10 Hythe Bridge Street, Oxford OX1 2EW

and in the United States by

OXBOW BOOKS

908 Darby Road, Havertown, PA 19083

(C) Oxbow Books and the individual contributors 2014

Paperback Edition: ISBN 978-1-78297-690-5

Digital Edition: ISBN 978-1-78297-691-2

A CIP record for this book is available from the British Library

All rights reserved. No part of this book may be reproduced or transmitted in any form or by any means, electronic or mechanical including photocopying, recording or by any information storage and retrieval system, without permission from the publisher in writing.

For a complete list of Oxbow titles, please contact:

\section{UNITED KINGDOM}

Oxbow Books

Telephone (01865) 241249, Fax (01865) 794449

Email: oxbow@oxbowbooks.com

www.oxbowbooks.com
UNITED STATES OF AMERICA

Oxbow Books

Telephone (800) 791-9354, Fax (610) 853-9146

Email: queries@casemateacademic.com

www.casemateacademic.com/oxbow

Oxbow Books is part of the Casemate Group

Cover Illustration: Marble head of Mithras from the Temple of Mithras, London. Now located in Museum of London. Reproduced with the kind permission of The Museum of London. 


\section{Contents}

Introduction: TRAC Past, Present and Future: Where to go from here?

Hannah Platts, John Pearce, Caroline Barron, Jason Lundock, Justin Yoo

A Historiography of the Study of the Roman Economy: Economic Growth, Development, and Neoliberalism

Matthew S. Hobson

Why Modern Economic Theory Applies, Even to the Distant Roman Past

Willem M. Jongman

Dalmatian Silvanus: A Cognitive Approach to Reinterpretation of the Reliefs

Representing Silvanus from Roman Dalmatia

Josipa Lulić

Votive Objects and Ritual Practice at the King's Spring at Bath

Eleri H. Cousins

Resurrecting Refuse at Pompeii: The Use-Value of Urban Refuse and its Implications for Interpreting Archaeological Assemblages

Kevin Dicus

Decline, Migration and Revival: Kom al-Ahmer and Kom Wasit, a History of a Forgotten City

Giorgia Marchiori

Small Finds and Roman Battlefields: The Process and Impact of Post-Battle Looting Joanne Ball

Methods and Difficulties in Quantifying Archaeological Vessel Glass Assemblages

Jonathan D. Prior

Pompeian Red Ware in Roman London: Insights on Pottery Consumption in Colonial Environments

Cristina Podavitte

Roman Sexuality or Roman Sexualities? Looking at Sexual Imagery on Roman Terracotta Mould-made Lamps

Sanja Vucetic

The Material Culture of Small Rural Settlements in the Batavian Area: a Case Study on Discrepant Experience, Creolisation, Romanisation or Globalisation?

Stijn Heeren 


\title{
Votive Objects and Ritual Practice at the King's Spring at Bath
}

\author{
Eleri H. Cousins
}

\section{Introduction}

Within the Roman site of Aquae Sulis, modern Bath, bubble up three hot springs, the largest of which, the King's Spring, produces over a quarter of a million gallons a day. During the Roman period the King's Spring was confined within a reservoir, which contained the flow of water and directed it to a massive bathing complex. Nearby was a temple, dedicated to the goddess Sulis Minerva, and offerings to this goddess have been recovered in great numbers from the reservoir of the spring. Other parts of Aquae Sulis have produced evidence of other major public buildings (Cunliffe 1989; Davenport; Poole and Jordan 2007: 2-5, 68-9), but this zone around the King's Spring, with its focus on the worship of Sulis Minerva, has always been seen as the monumental heart of the site.

Excavations at the reservoir of the spring have uncovered a wealth of votive objects, including coins, metal vessels, 'curse tablets', and small ex-votos ranging from combs to intaglios to military equipment (Henig et al. 1988). However; interpretations of this rich source of evidence for ritual practice at this important site have often lacked contextual depth. The personal choice and experience of the dedicator is rarely considered when asking why objects were chosen for deposition, and previous phases in the life cycle of the object are rarely, if ever, discussed, even when the object is obviously worn through earlier, 'functional', use. Even the objects' ex-voto nature is underdeveloped theoretically, with little attention paid to the manner of their deposition or to the possible ritual motivations behind their relinquishment. Finally, there has been almost no discussion of how depositional practice at the King's Spring may fit within broader trends in Roman Britain.

This paper seeks to re-examine the motives behind ritual deposition of objects at the King's Spring, and to move towards a more theoretically robust model. I begin by discussing the wider background of ritual deposition in water in Iron Age and Roman Britain, and argue that the implications of a watery context must be central to our understanding of ritual practice at the King's Spring. After examining the characteristics of the reservoir context, I take as a case study the deposition of the so-called 'curse tablets', as well as that of the pewter vessels. The presence of used, indeed well-worn, vessels, when taken together with the many tablets from the spring recording the dedication of unrecovered stolen items to the goddess, suggests that ex-voto dedication at the reservoir may have functioned, in part, as a way of harnessing and controlling loss or decay through ritual. In this brief case study, I take, therefore, a first step 
towards a more holistic interpretation of the votives found in Sulis' reservoir, and I help to move the water, and the implications of a watery context for ritual activity at Bath, back to the centre of discussion. This more nuanced approach sheds new light on the relationship between Sulis Minerva, her spring, and her worshipers, and thus on a site which, though renowned, may not yet be truly well-known.

\section{Ritual relinquishment: a brief look at the wider context}

This paper focuses on votive objects from a watery place. I begin, therefore, by discussing the implications, for both methodology and meaning, of water and watery contexts in the archaeology of Roman and Iron Age Britain. It is not unusual for archaeological objects to be found in watery contexts, whether they emerge from dredging of modern rivers and ponds, are found in now-dry stream beds, or are uncovered in man-made water spaces such as wells. Early scholars often focused on, what Bradley has termed, 'practical interpretations' for these finds and their loss in antiquity (Bradley 1990 (second edition 1998): 23-28). A.W. Franks, for example, when presenting the Waterloo Helmet to the London Society of Antiquaries, noted its stylistic resemblance to the Battersea Shield, and suggested that it was "not impossible that the helmet may have belonged to the same warrior killed in some struggle' (Franks 1864-7: 343). John Clayton, when confronted with the thousands of coins from Coventina's Well in Northumberland, could not believe that they had been deposited as votives, on the grounds that 1) the copper would have spoiled the water, and 2) the priests would never have allowed so much money to escape their clutches (Clayton 1880: 6, 31). He concluded instead that 'some panic' in a time of military crisis must have prompted their concealment (Clayton 1880: 47). Battle scenarios or accidental loss during river crossings explained the deposition of items of obvious high value. For smaller objects and coins, both the accident scenario (Fitzpatrick and Scott 1999: 117) and the modern parallel of the wishing well have been invoked (Henig 1988: 5; Cunliffe 1988: 361). It was assumed people dropped these little objects into watery environments as a matter of casual practice, often with no more motive than a little light-hearted superstition or desire for good luck.

Prehistoric archaeologists in Britain have recognized for some time that the deposition of artefacts in water in the pre-Roman Iron Age was more deliberate and laden with ritual meaning than earlier scholars were willing to or perhaps even comfortable with acknowledging (Hill 1995; Bradley 1998). Without written sources it is impossible to parse the precise epistemological motivations for these depositions, however, they seem to form the focus of rituals which both served as a connection between the depositor and the chthonic powers - perhaps even deities of earth and water, and which played a role in the construction of the depositor's social prestige and position (Merrifield 1987: 22-30). Thus these objects, in prehistoric archaeology, have gone from being understood as casual losses with limited potential for interpretation beyond typological considerations, to being seen as windows into the entanglement of social and ritual practice in the Iron Age, and into the relationship between human individuals, human communities, and divine or supernatural spheres (Bradley 1998: 181ff).

Nevertheless, they are opaque windows. Ancient objects found in watery places are usually, by the nature of the medium in which they are located, almost completely lacking in archaeological context (Bradley 1998:6). Paradoxically, the very medium of water, which alerts us to their ritual status, has deprived us of most of our usual tools for reconstructing patterns of meaning and use. The artefact's likely movement through the water from its original place of deposition means 
that often we cannot begin to reconstruct the ritual's place within the larger natural landscape, and, apart from possible stylistic and typological considerations inherent in the artefact itself, we are usually left with only vague ideas about the dates of depositions and consequently chronological change in ritual behaviour from one deposition to the next.

This awareness of ritual deposition, which started in the study of Britain in the Iron Age, has trickled forward to some extent into our understanding of deposition in the Roman period. Structured deposition in wells and pits in particular have been well-studied, in part because the stratified nature of these contexts has demonstrated that there is an order, or patterning, to assemblages previously seen as simply rubbish in-filling (Millett and Graham 1986: 159; Merrifield 1987: 40ff; Clarke 1997; Fulford 2001). Late-Roman vessel hoards have also been reconsidered in the last 20 years, with many scholars no longer seeing them universally as crisis hoards, put away in times of warfare and never recovered. Instead, many may not have been intended to be recovered but were, in fact, buried in a form of ritual relinquishment. Such actions perhaps appear strange and even illogical to modern eyes, but they become comprehensible when viewed in the broader context of ritual deposition (Poulton and Scott 1993; Millett 1994; Gerrard 2009; though see Jones 1994 and more recently Lee 2009: 83-84 for rebuttals).

Unlike deposits in wells or hoards of plate, the material from the King's Spring was never thought to be secular in nature; the spring's location near a temple and the inscribed votives found within the spring itself precluded such an interpretation. Nonetheless the motivations of the worshipers who deposited these votives have not been fully considered in the light of the larger trends of ritual relinquishment I have briefly outlined above. To what extent and in what way should we take these trends into account when considering votive depositions at places like the King's Spring?

E. Sauer, in his discussion of the deposition of coins at the spring at Bourbonne-les-Bains in France, has argued strongly against seeing any relation between Iron Age deposition in 'watery contexts', particularly rivers and bogs, and Roman period coin deposition in springs (Sauer 2005: 95-100). He makes the valid point that veneration of water is an 'almost universal' human cultural trait, although he acknowledges that the form of that veneration may be culturally specific (Sauer 2005: 97). He also demonstrates that for Gaul and the Germanies, there is no convincing example of unquestionably Iron Age coin deposition at springs (Sauer 2005: 100-104). On the other hand, this does not hold true for Britain, where at least one certain example, at Stoke (Kent) is known (Holman 2005: 275-277). Nonetheless Sauer goes too far in his emphasis on the need to prove an 'evolutionary chain' for the 'ritual evolution of the deposition of prehistoric objects in rivers and Roman coins in springs', before we can suggest that practices in the Roman period are in some way connected to earlier non-Roman practice (Sauer 2005: 100). The concept of the development of human culture as an evolutionary progression which can be tracked in the archaeological record has been thoroughly and convincingly critiqued in recent decades, and cultural change should be seen as a complex mechanism of give-and-take and dialectical revision, rather than proceeding linearly through well-defined and clearly linked intermediate points (for Romanisation specifically, see e.g., Barrett 1997; Woolf 1998: 7-23; for historical overview of theoretical trends see Trigger 2006: 436ff; Renfrew and Bahn 2012: 376-80, 463ff) Even if the possibility of continuity between the pre-Roman Iron Age and the Roman period is rejected (and I do not reject it), the methodology used in the study of the Iron Age is worth adopting. Its focus on the medium in which deposition occurs and on the practice of relinquishment itself brings our attention back to themes which can be lost in site reports that may focus overly on votive typology to the neglect of votive context. 


\section{The setting: the reservoir at the King's Spring}

The reservoir, built in Roman times, was covered by structural modifications from the Middles Ages onwards, and investigation of the Roman layers was for a long time impossible. The reservoir's construction was examined in the 19th century, but it was not until 1979 that opportunity for excavation was afforded by the detection of harmful bacteria contaminating the spring water - a discovery which required the emptying of the modern bath (Cunliffe and Davenport 1985: 21). The excavation from 1979 to 1980 confirmed and expanded upon the findings of the 19th century, and also uncovered a significant proportion of a sandy deposit at the bottom of the reservoir, which was found to contain a wealth of votive objects.

The nature of the reservoir context can be briefly described. In the pre-Roman period, the spring would have been open to the elements, bubbling up through a sandy fissure in the black mud-like surroundings of the river valley (Cunliffe 1988: 1). The reservoir tank was one of the first structures to be constructed in the Roman period, most likely during the Flavian era. It had masonry walls embedded in the ground surrounding the spring, and was lined with lead for water-proofing purposes. This created an irregular octagonal tank measuring about 15 metres by 12 metres, with an outflow to the large bath complex to its south (Cunliffe and Davenport 1985: 39-42). The reservoir had no bottom or filtering mechanism by which the spring water entered; thus sand and silt from the spring's fissure would come up into the reservoir along with the water. This created a quicksand-like environment at the bottom of the tank, into which objects thrown into the reservoir would sink and move about over the centuries (Cunliffe and Davenport 1985: 43). There is, as a consequence, no stratigraphic sequence to the votive deposit, and no way of determining, at least through stratigraphic means, which objects were deposited earliest. Meanwhile, in terms of the experience of worshipers in antiquity, the presence of this sand meant that objects thrown into the reservoir could not be seen after deposition: we should not imagine a wishing-well atmosphere, with coins glinting clearly through clean water.

The reservoir is, to a large degree, a closed context, unlike a river where artefacts might move a great distance from their place of deposition. Some votives were probably washed out of the reservoir via various exit pipes, so we have, perhaps, lost artefacts. For those objects that remain in the reservoir, however, we know how they were deposited: they were tossed in from the edge of the pool.

Like a well, and again unlike a natural water feature, the reservoir is man-made, and decisively so; it is, in fact, one of the most impressive feats of engineering in Roman Britain. Herein, however, lies a tension at the heart of the nature of the reservoir. It is a man-made setting, but it was a natural one, and its power, and the power of its goddess, stems from a continued understanding of it as a place of natural forces; the steam and dynamic motion of the surface would have been a constant reminder of this. The container is man-made, but the water within it is of the earth.

\section{The votives}

Due to the lack of stratigraphy, we cannot do any fine-grained analysis of change in ritual practices at the reservoir across the centuries. At the same time, however, due to the variety and number of objects found, we have an opportunity to think more broadly about the meaning of deposition in water at Bath than we are able to when a single sword or shield is found in a river. In all, several hundred artefacts have been recovered from the spring, together with several thousand coins. Many of the objects have no obvious connection to each other, and create no 
clear pattern. They include items of personal adornment, e.g. fibulae, combs, miscellaneous jewellery, as well as objects related to various crafts: spindle whorls, metal ingots, a collection of intaglios seemingly by the same artist, and even a catapult washer.

In addition to these varied votives, there are three more discrete categories of votives recovered from the spring. The first are coins. Coins were by far the most common find from the reservoir; over 12,000 were recovered during the 1979-80 excavations (Walker 1988: 281). They span the whole period of Roman occupation, and even include eighteen Celtic coins. Due to the stratigraphic problems of the reservoir, however, it is impossible to know whether the Celtic coins were thrown in before, or during, the Roman period (Sellwood 1988: 279). The second category is the so-called curse tablets: petitions to Sulis for justice and vengeance, scratched onto thin sheets of pewter, tin, and lead. Around 130 of these have been recovered, although many are too fragmentary to read. A final category could perhaps be termed 'ritual vessels': jugs, pans, bowls, and plates, which are mostly made of pewter, although a few are in silver or bronze. These are often dedicated to Sulis Minerva via an inscription and usually show signs of wear and tear.

The challenge before us is how we may best use this votive material to further our understanding of religious activity at Bath. Most discussions of the votive objects have been fairly anecdotal in nature: votives have tended to be approached casually and individually with little rigorous or systematic evaluation of the votive categories as a whole, or of the possible relationships between the groups. Thus the one anatomical ex-voto has been cited as proof of Sulis' healing, 'Minerva Medica', aspect (Sauer 1996: 65), the catapult washer must have been dedicated because she was the goddess of war, and the various other objects from the 'mundus muliebris', as Henig put it, were because they were appropriate to her as a female deity (Henig 1988: 5).

This tactic of matching objects to attributes is a reasonably common approach to syncretic deities, yet in its lack of specificity it is ultimately of limited utility. It is also fundamentally flawed in the assumption that because Sulis (or any other syncretic deity) is Sulis Minerva (or any other classical god), she must incorporate into her identity all the various classical incarnations of Minerva (and even Athena) from Mediterranean Greco-Roman culture. The mechanisms which led to the equation of particular 'native' deities with Greco-Roman ones are usually unrecoverable, but, as Georg Wissowa pointed out in his initial discussion of interpretatio romana, we should be reluctant to assume that careful theological inquiries led to these equations rather than the vagaries of individual experience and understanding (Wissowa 1916-19: 24ff). In other words, we cannot assume that the aspect or aspects of Sulis which led to her initial equation with Minerva are easily identifiable in the worship of the later goddess Sulis Minerva. In the specific case of the votives, this means we are probably on more solid ground thinking about what the choice of votives tells us about Sulis Minerva's worshipers, than about what that choice tells us about Sulis Minerva.

Furthermore, the larger votive categories, which I outlined above, have usually been treated separately from each other, with little attempt made to analyse the ways in which they are (or are not) part of a more universal attitude towards ritual at the reservoir. In part this is a side effect of the specialist knowledge needed for full publication of these classes of artefacts; intaglios, coins, tablets and pewter vessels, were each studied by different scholars, which renders synthesis difficult. In what follows, I wish to begin to remedy this lack of synthesis by considering, in particular, the 'curse tablets' and the pewter vessels in conjunction with each other. 


\section{The 'curse tablets'}

Around 130 so-called curse tablets, predominantly of pewter, but a few wholly of tin or lead, were found in the reservoir at Bath. The majority of those that can be deciphered are inscribed with messages to the goddess Sulis, and most of these concern the theft of an object and a request that the goddess deliver retribution on the thief. The practice of inscribing a lead (or lead alloy) tablet with a request for divine manipulation of an interpersonal problem seems to have begun in the Greek-speaking world, with the earliest examples appearing in Attica and Sicily in the fifth and fourth centuries B.C., nearly a millennium before the Bath tablets (Gager 1992: 5). The tablets from Bath have been understood primarily through analyses of their written texts, and through analogies with comparable material from the continent (Tomlin 1988b; Adams 1992; Mullen 2007a; Mullen 2007b; Kropp 2008). This work, starting with Roger Tomlin's initial publication of the Bath tablets, has been justifiably cautious about the term 'curse tablet', with its connotations of dark magic (Tomlin 1988b: 49). The Bath material has often instead been referred to as comprising 'judicial prayers' - petitions to Sulis about legitimate grievances and couched in language with many legal parallels (Tomlin 2002: 167; Kropp 2008). The term 'judicial prayer' was coined by H.S. Versnel, as an alternative to the word defixio often used to describe curses (Versnel 1991). These 'judicial prayers', in Versnel's eyes, differ from the defixio in numerous ways:

1) They often contain supplication, or a vow, rather than coercion or ordering of the deities or daemons

2) The intended victim is perceived as guilty of a crime, rather than simply a rival of the curser

3) The curser, rather than being anonymous, is often named, again implying a sense of right, rather than wrong, doing (Versnel 1991: 62).

The Bath tablets dedicated to Sulis Minerva have all of these characteristics; the difference between supplication of the god and coercion is what truly marks out Versnel's 'judicial prayers' as a different practice from the rest of scholarship's 'curse tablets'.

It is important, however, not to take this too far. Curses and judicial prayers on lead alloy tablets are still clearly related practices, and there are texts from throughout the ancient world which straddle the line between the two (Versnel 1991: 64ff). In 'curses' and 'judicial prayers', there is a victim who is to be forced into a fate they do not want (although in judicial prayers, the fate may often be escaped or rescinded if justice is received and compensation made for the original offence).

In practical terms, however, when approaching the Bath tablets, it must be noted that the magical, indeed sinister, connotations of curse tablets from elsewhere should not necessarily be the main force driving our understanding of the Bath tablets and their relationship to votive behaviour occurring at Bath. More important is the petitionary language of the texts, the ideas the texts present about the role of Sulis in her worshipers' lives, and the implications about the physical placement of such prayers inherent in their deposition in the spring, and their further concealment through rolling and folding.

In addition to the qualities which mark judicial prayers, most British tablets, including the Bath corpus, follow a rather different pattern with regards to subject matter from the curse tablets of the continent. While curse tablets in other parts of the Roman Empire have a variety of goals, ranging from success in love, to business, to sports and competition, and often emphasise causing physical harm to enemies (Gager 1992; Kropp 2008), tablets in Britain almost invariably deal with theft. At Bath, for instance, apart from a single tablet concerned with perjury, and the 
various undecipherable or extremely fragmentary texts, no tablet 'can be said to have been not prompted by theft' (Tomlin 1988b: 60). Furthermore, these tablets respond to these thefts in a noteworthy way. Tab. Sulis 8 , for example, reads:

I have given to the goddess Sulis the six silver coins which I have lost. It is for the goddess to exact (them) from the names written below: Senicianus and Saturninus and Anniola. The written page (has) been copied out.

Reverse: An(n)iola / Senicianus / Saturninus

This tablet illustrates some standard features of the way petitioners to Sulis talk about theft. They usually do not seek to redeem the lost object; rather, they are dedicating it to the goddess. With the stolen item now Sulis' property, it becomes her responsibility to deal with the thieves - not on behalf of the original petitioner, but on behalf of herself. The practical consequence of this is that the petitioner is able to harness the loss they experienced through the theft and to reclaim control over the lost object, without physically regaining the object. Through the use of ritual, the petitioner goes from powerless victim to having agency over the fate of his or her possessions again.

What role does the placement in water, the final act of the ritual, play in this process? Perhaps the medium can be thought of as connected to this transformation from stolen object to dedicated, sacred one, since anthropologically water often appears as an element in flux, and through its own ever-changing state, able to effect transformation in other objects or people (Strang 2004: 61-65, 91ff; Kamash 2008; Oestigaard 2011: 38-42).

\section{The pewter and silver vessels}

This understanding of the motivations behind tablets like number 8 can help us to put a more nuanced slant on the deposition of plates and vessels in the reservoir as well.

In total, 24 vessels, including bowls, plates, jugs, pans (or paterae), and more unique items such as an ink pot and a candleholder, have been recovered from the reservoir or the reservoir drain, both in the 19th century and during the 1979-1980 excavations (Henig et al. 1988: 9-21). The vast majority are pewter, apart from two silver pans and one small bronze one. The bronze vessel is of the Rudge Cup type, presumed to depict Hadrian's Wall, and seems likely to have been a private votive and in a separate category from the other plate (it is the only vessel which was marked with the name of a dedicator). It will therefore not be discussed at length here.

Many of the vessels show signs of wear or even soldered repair, indicating that their deposition in the reservoir was the last act in a longer life history of the object, a life history involving active use. Many of the vessels, particularly the jugs and pans, may have been in some way involved in rituals in the cult of Sulis Minerva, and deposited in the goddess' water at the end of their life history (Cunliffe 1988: 361). Six of the seven silver or pewter pans bear inscriptions to Sulis Minerva (Tomlin 1988a: 55-57); their form, the patera type often depicted on altars, combined with the dedication, lends support to the 'temple plate' theory. Other vessels show signs of having been deliberately damaged beyond practical use before deposition. One vessel, a bowl with a pedestal, seems to have been deliberately squashed (Pollard 1985: 60). Another, a plate, was repeatedly perforated with a sharp instrument before deposition (Fig. 1). The damage to this last piece has not, to the best of my knowledge, been discussed or illustrated before; it is represented only by a profile line drawing in the report of objects from the spring (Henig et al. 1988: 11, cat. no. 11.) 
The assemblage of vessels and their placement in the spring have been considered unproblematic - the simple disposal of unwanted temple plate. This may well be what it represents but, again, those methods of disposal have not been considered in light of the larger ritual framework at the reservoir. We have here a similar situation with regards to controlling loss of objects of significance, as is demonstrated by the handling of theft in the tablets. Having reached the end of their functionality, the vessels need to be discarded, but due to their previous ritual significance that discard cannot be casual. They are given over to the goddess, rather than simply thrown away; thus their disposal does not need to entail a potentially painful loss of something of symbolic value - the water enables them to retain their sacred status even after their functionality is gone.

Deposition of the tablet and vessels, therefore, fulfilled similar functions. The mundane cloaks, gloves, and coins recorded as stolen in the tablets may not have had the same sacred, symbolic value as the vessels during their life history, but once lost they take on an added importance, since their loss brings about feelings of helplessness and violation in their owners. Those feelings are then mitigated by communication with the goddess and dedication-by-proxy of the object, allowing the victims of theft or of time to regain control of both the situation and the object, and to refashion the loss to be a willing one - a voluntary handing-over of ownership claims to the goddess.

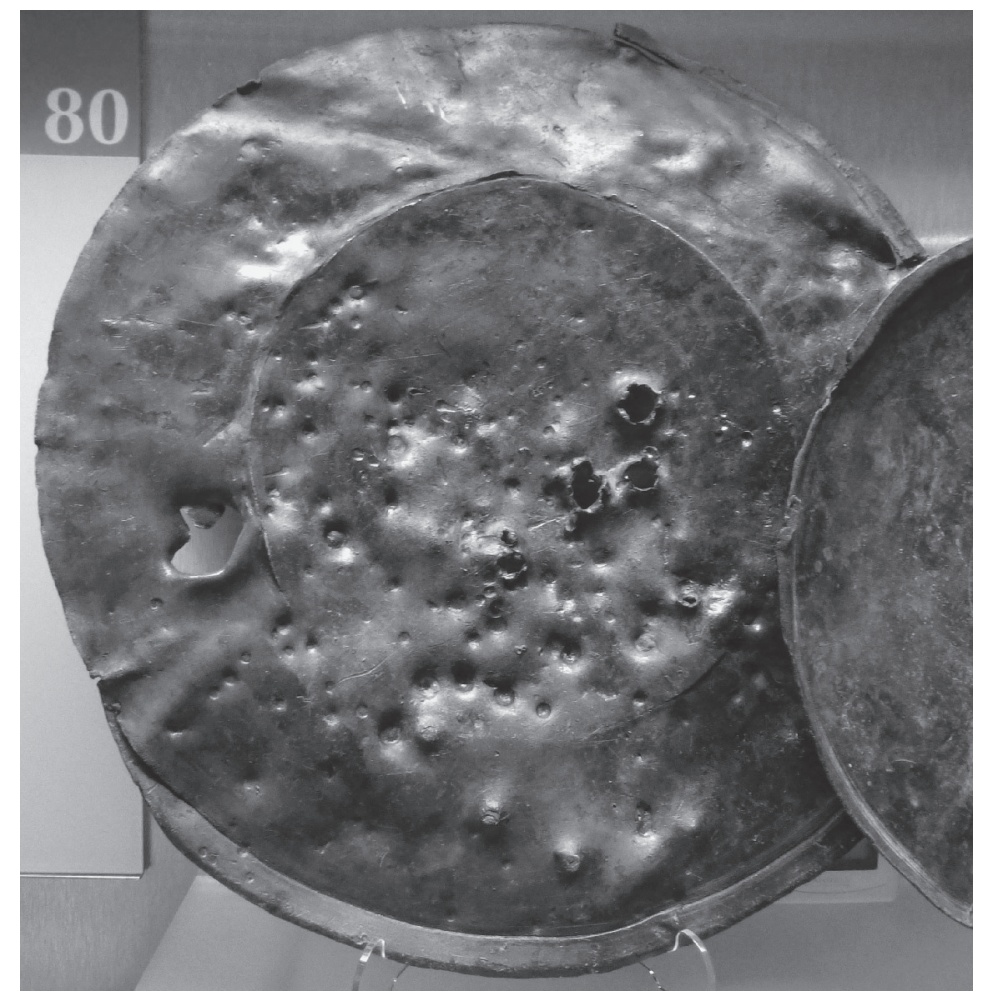

Figure 1: A deliberately pierced pewter plate deposited in the reservoir (Roman Baths Museum 1985.14.c.2; Copyright Bath \& North East Somerset Council). 


\section{Ritual substances: pewter and water}

The two categories discussed here are linked by their material, pewter, as well as the seeming motivations behind their deposition, and it is thus worth taking a moment to consider the place and meaning of pewter in Roman Britain. On the whole, the production of pewter (tin alloys, usually mixed with lead) objects on a wide scale does not become common in the province until the 3rd century and later (Lee 2009: 50). The region around Bath seems to have been a focus for this industry, for instance at Camerton and Lansdown, although there is no proof that the vessels found at Bath were made at these nearby manufacturing sites. Lead, mostly in the form of galena (lead and silver ore) outcroppings, was also mined in the region, particularly in the Charterhouse valley, only 18 kilometres from Bath (Todd 2007).

As for Roman attitudes towards pewter, terminology in our sources is usually unclear, but it does seem that there is an (understandable) association between the appearance of pewter and silver. Thus Pliny refers to one lead/tin combination as argentarium (N.H. XXXIV, 160-1). The association is not necessarily a positive one; Pliny implies that the term argentarium can be abused to raise the price of more debased alloys, and Suetonius accuses the emperor Vitellius of replacing gold and silver offerings in temples with ones of brass and tin/pewter (stagnum) (Beagrie 1989: 170). Our sources, however, perhaps display an elite judgment towards the less valuable material; the message to take away may simply be that pewter, in looks at any rate, could be seen as a substitute for silver, and from a materiality standpoint, we can potentially justify thinking about pewter and silver votive objects as a single group sharing aesthetic visual qualities.

This observation applies particularly to the tablets. In discussions of 'curse tablets', both at Bath and elsewhere, lead has been understood as the standard material, even when, as at Bath, there are as many pure tin tablets as pure lead ones, and most are a mixture. The emphasis on lead has stemmed from a belief in scholarship that lead had particularly strong chthonic qualities in antiquity, and from the idea that its heaviness and dull colour were, prima facie, easily associated with death and suitable to a cursing context (Tomlin 1988b: 81; Gager 1992: 4; see Faraone 1991: 7 for discussion of the weaknesses of this rationale).

If we, however, think of the tablets as pewter, rather than lead, the connotations change. The tablets, instead of being made with a death-related material, are formed of a 'wishful' version of silver, which, as a material for rich offerings, has much more 'positive' and orthodox religious connotations. The tablets are also, then, potentially to be grouped with the pewter vessels from the reservoir through their material as well as through the motivations behind their deposition.

The other material discussed in this paper has been water. I opened with a discussion of the ways water has been thought to act in the wider chronological and geographical context of Britain. What has this study implied about Sulis Minerva's water in particular?

Understanding of the properties of Sulis' water has, perhaps, been excessively influenced by the medicinal role of the Bath waters from the 18th century onwards. It is starting to be noted that the healing aspect of Sulis' cult is perhaps not as certain as has usually been assumed, and we may need to reconsider our assumptions about medicinal use of the hot springs in the Roman period (Davenport 2000: 21; Revell 2009: 128).

Be that as it may, there need not be one meaning or purpose to Sulis' water. It may be acting in differently in different places, for example in the reservoir versus the baths. The case study here has suggested that in the reservoir the water acts as a medium that enables relinquishment. By using the water as a place of ritual deposition, the worshipers are able to surrender ownership 
of meaning-laden possessions in a way that mitigates the potential long-term emotional effects of loss. Such a model helps to answer the central problem, to modern eyes, of why someone would voluntarily dedicate objects in such a way that their dedication is invisible after the act. The point is not to gain prestige by having a visible, rich, dedication on display in the temple, neither is it the social after-effects of the ritual. Rather, the point is to use the ritual and the water as means of closure for tensions concerning ownership, loss, and the material intersection of profane and divine.

This motivation differs from votive practices at many Mediterranean temple sites, where a desire for display has often been taken by scholars to be a principal prompt for dedication (Price 1984: 146; Beard 1991; Rüpke 2007: 154ff). At Bath, the desire instead seems to be to put objects beyond recovery in a watery place, which is also a natural place transformed into a man-made one. This last tension between the natural and the artificial is a particularly interesting one that merits further work, though it is beyond the scope of this paper to address it in detail.

\section{Conclusions: avenues for further work}

Due to space constraints, I have not discussed coins and small votives in depth here, but similar contextualization can, and should, be done for them as well. The coin assemblage, the largest object assemblage from the reservoir, is often understood through casual analogies with modern wishing-well behaviour. This is an analogy that is already false in terms of the physical characteristics of the reservoir. The decision to throw a coin into a wishing-well is prompted by seeing other coins thrown in by other people, already shining at the bottom. As discussed above, these visual prompts would not have existed at Sulis' spring due to the environmental conditions. Even apart from this, however, using the wishing-well analogy is probably anachronistic, and more work in general needs to be done on when coins are thrown into water, what ritual actions might accompany them, and what value is placed on them, whether in and of themselves as money or as proxies for other things. The connections between practice at Bath and at other similar sites with large coin assemblages, e.g. Coventina's Well (Northumberland) and the riverine ritual deposit at Piercebridge (Durham) should be explored (Allason-Jones and McKay 1985; Walton 2008); recent work has examined the similarities and differences between coin profiles at these sites, but more can and should be done (Walton 2012: 155ff).

Finally the great variety of other ex-votos has usually been shoehorned into one aspect or another of the classical goddess Minerva. The limited utility of this approach to syncretic deities has been laid out above. As with the tablets and vessels, if we think about the interests and concerns of the worshipers, rather than the identity of Sulis, we will perhaps move further. Thus, instead of having a womanly warrior goddess who weaves and heals, we have worshipers of Sulis from complex and varied backgrounds, each tossing possessions of personal significance - most likely significance unrecoverable to us - into the steaming waters that are the only thing we can know for certain was utterly linked to Sulis.

This paper has certainly not solved all the problems of what people were doing at Sulis' reservoir, and why. Yet I hope in this brief discussion that I have done two things: 1) I have made a first step towards a more holistic interpretation of the votives found in the sacred reservoir, and 2) I have helped to move the water, and the implications of a watery context for ritual activity at Bath, back to the centre of debate. At Bath, noticing the ways in which water can act, and how deposition in water relates to deposition and ritual loss elsewhere in RomanoBritish ritual, is an important corrective to our idea of Bath as a place with a syncretic goddess 
but nonetheless mostly non-indigenous, Mediterranean, ritual forms. While the temple might be tetrastyle Corinthian, the reservoir right next to it, and roughly the same size, is a place where insular practice meets Roman engineering and architectural form. But the implications of that cultural blending are a topic for another day.

Faculty of Classics, University of Cambridge

\section{Bibliography}

\section{Ancient Sources}

Suetonius (Translated by J.C. Rolfe 1970). The Lives of the Caesars. London: William Heinemann. Pliny (Translated by H. Rackham 1968). Natural History. London: William Heinemann.

\section{Modern Sources}

Adams, J.N. 1992. British Latin: The Text, Interpretation and Language of the Bath Curse Tablets. Britannia 23: $1-26$.

Allason-Jones, A. and McKay, B. 1985. Coventina's Well: A shrine on Hadrian's Wall. Chesters Museum: The Trustees of the Clayton Collection.

Barrett, J.C. 1997. Romanization: a critical comment. In D.J. Mattingly (ed.) Dialogues in Roman imperialism: power, discourse, and discrepant experience in the Roman Empire. Journal of Roman Archaeology Supplementary Series 23. Portsmouth: Journal of Roman Archaeology: 51-66.

Beagrie, N. 1989. The Romano-British Pewter Industry. Britannia 20: 169-191.

Beard, M. 1991. Ancient literacy and the function of the written word in Roman religion. In M. Beard et al Literacy in the Roman world. Journal of Roman Archaeology Supplementary Series 3. Ann Arbor: Journal of Roman Archaeology: 35-58.

Bradley, R. 1990. (2nd ed. 1998). The Passage of Arms: An archaeological analysis of prehistoric hoard and votive deposits. Oxford: Oxbow Books.

Clarke, S. 1997. Abandonment, Rubbish Disposal and 'Special' Deposits at Newstead. In K. Meadows, C. Lemke and J. Heron (eds.) TRAC 96: Proceedings of the Sixth Annual Theoretical Roman Archaeology Conference, Sheffield 1996. Oxford: Oxbow Books: 73-81.

Clayton, J. 1880. Description of Roman Remains discovered near to Procolitia, a Station on the Wall of Hadrian. Archaeologia Aeliana, New Series 8: 1-49.

Cunliffe, B. (ed.). 1988. The Temple of Sulis Minerva at Bath. Volume 2: The Finds from the Sacred Spring. Oxford: Oxford University Committee for Archaeology.

Cunliffe, B. 1989. The Roman Tholos from the Sanctuary of Sulis Minerva at Bath, England. In R.I. Curtis (ed.) Studia Pompeiana et Classica: In Honor of Wilhelmina F. Jashemski. Volume II: Classica. New Rochelle: A.D. Caratzas: 59-86.

Cunliffe, B. and Davenport, P. 1985. The Temple of Sulis Minerva at Bath: Volume 1(I) The Site. Oxford: Oxford University Committee for Archaeology.

Davenport, P. 2000. Aquae Sulis: The Origins and Development of a Roman Town. Bath History 8: 6-26.

Davenport, P., Poole, C., and Jordan, D. 2007. Archaeology in Bath: Excavations at the New Royal Baths (the Spa) and Bellott's Hospital 1998-1999. Oxford: Oxford Archaeology.

Faraone, C.A. 1991. The Agonistic Context of Early Greek Binding Spells. In C.A. Faraone and D. Obbink (eds.) Magika Hiera: Ancient Greek Magic and Religion. Oxford: Oxford University Press: 3-32.

Fitzpatrick, A.P. and Scott, P.R. 1999. The Roman Bridge at Piercebridge, North Yorkshire-County Durham. Britannia 30: 113-132.

Franks, A.W. 1864-7. Remarks. Proceedings of the Society of Antiquaries, Second Series 3: 343-4. 
Fulford, M. 2001. Links with the Past: Pervasive 'Ritual' Behaviour in Roman Britain. Britannia 32: 199-218. Gager, J.G. (ed.). 1992. Curse Tablets and Binding Spells from the Ancient World. Oxford: Oxford University Press.

Gerrard, J. 2009. The Drapers' Garden Hoard: A Preliminary Account. Britannia 40: 163-184.

Haselgrove, C. and Wigg-Wolf, D. (eds.). 2005. Iron Age Coinage and Ritual Practices. Studien zu Fundmünzen der Antike 20. Mainz: P. von Zabern.

Henig. M, et al. 1988. Objects from the Sacred Spring. In B. Cunliffe (ed.) The Temple of Sulis Minerva at Bath. Volume 2: The Finds from the Sacred Spring. Oxford: Oxford University Committee for Archaeology: 5-35.

Hill, J.D. 1995. Ritual and rubbish in the Iron Age of Wessex: a study on the formation of a specific archaeological record. British Archaeological Reports British Series 242. Oxford: Tempus Reparatum.

Holman, D. 2005. Iron Age coinage from Worth, Kent and other possible evidence of ritual deposition in Kent. In C. Haselgrove and D. Wigg-Wolf (eds.) Iron Age Coinage and Ritual Practices. Studien zu Fundmünzen der Antike 20. Mainz: P. von Zabern: 265-286.

Jones, C.J. 1994. Romano-British Precious Metal Hoards: Some Comments on Martin Millett's Paper. In S. Cottam, D. Dungworth, S. Scott and J. Taylor (eds.) TRAC 94: Proceedings of the Fourth Annual Theoretical Archaeology Conference, Durham 1994. Oxford: Oxbow Books: 107-117.

Kamash, Z. 2008. What lies beneath? Perceptions of the ontological paradox of water. World Archaeology 40.2: 224-237.

Kropp, A. 2008. Defixiones: Ein aktuelles Corpus lateinischer Fluchtafeln. Speyer: Kartoffeldruck-Verlag kai Broderson.

Lee, R. 2009. The Production, Use and Disposal of Romano-British Pewter Tableware. British Archaeological Reports British Series 478. Oxford: Archaeopress.

Merrifield, R. 1987. The Archaeology of Ritual and Magic. London: Batsford.

Millett, M. 1994. Treasure: Interpreting Roman Hoards. In S. Cottam, D. Dungworth, S. Scott and J. Taylor (eds.) TRAC 94: Proceedings of the Fourth Annual Theoretical Archaeology Conference, Durham 1994. Oxford: Oxbow Books: 99-106.

Millett, M. and Graham, D. 1986. Excavations on the Romano-British small town at Neatham, Hampshire, 1969-1979. Winchester: Hampshire Field Club in co-operation with the Farnham and District Museum Society.

Mullen, A. 2007a. Evidence for Written Celtic from Roman Britain: A Linguistic Analysis of Tabellae Sulis 14 and 18. Studia Celtica 41: 31-46.

Mullen, A. 2007b. Linguistic Evidence for 'Romanization': Continuity and Change in Romano-British Onomastics: A Study of the Epigraphic Record with Particular Reference to Bath. Britannia 38: 35-61.

Oestigaard, T. 2011. Water. In T. Insoll (ed.) Oxford Handbook of the Archaeology of Ritual and Religion. Oxford: Oxford University Press: 38-50.

Pollard, S. 1985. Conservation of Pewter Objects from the Roman Reservoir at Bath. In G. Miles and S. Pollard (eds.) Lead and Tin: Studies in Conservation and Technology 3. London: United Kingdom Institute for Conservation of Historic and Artistic Works: 57-63.

Poulton, R. and Scott, E. 1993. The Hoarding, Deposition and Use of Pewter in Roman Britain. In E. Scott (ed.) Theoretical Roman Archaeology: First Conference Proceedings. Aldershot: Avebury: 115-132.

Price, S.R.F. 1984. Rituals and Power: The Roman imperial cult in Asia Minor. Cambridge: Cambridge University Press.

Renfrew, C. and Bahn, P. 2012. Archaeology: Theories, Methods and Practice, 6th edition. London: Thames and Hudson.

Revell, L. 2009. Roman Imperialism and Local Identities. Cambridge: Cambridge University Press.

Rüpke, J. 2007. Religion of the Romans. Gordon, R. (trans.) Cambridge: Polity.

Sauer, E. 2005. Coins, cult and cultural identity: Augustan coins, hot springs and the early Roman baths at Bourbonne-les-Bains. Leicester Archaeology Monographs 10. Leicester: University of Leicester, School of Archaeology and Ancient History. 
Sauer, E. 1996. An Inscription from Northern Italy, the Roman Temple Complex in Bath and Minerva as a Healing Goddess in Gallo-Roman religion. Oxford Journal of Archaeology 15(1): 63-93.

Sellwood, L. 1988. The Celtic Coins. In B. Cunliffe (ed.) The Temple of Sulis Minerva at Bath. Volume 2: The Finds from the Sacred Spring. Oxford: Oxford University Committee for Archaeology: 279-280.

Strang, V. 2004. The Meaning of Water. Oxford: Berg.

Todd, M. 2007. Roman Mining in Somerset: Excavations at Charterhouse on Mendip 1993-1995. Exeter: Mint Press.

Tomlin, R.S.O. 1988a. Inscriptions on Metal Vessels. In B. Cunliffe (ed.) The Temple of Sulis Minerva at Bath. Volume 2: The Finds from the Sacred Spring. Oxford: Oxford University Committee for Archaeology: 55-57.

Tomlin, R.S.O. 1988b. The Curse Tablets. In B. Cunliffe (ed.) The Temple of Sulis Minerva at Bath. Volume 2: The Finds from the Sacred Spring. Oxford: Oxford University Committee for Archaeology: 59-280.

Tomlin, R.S.O. 2002. Writing to the gods in Britain. In A. Cooley (ed.) Becoming Roman, Writing Latin?: Literacy and Epigraphy in the Roman West. Journal of Roman Archaeology Supplementary Series 48. Portsmouth: Journal of Roman Archaeology: 165-179.

Trigger, B.G. 2006. A history of archaeological thought, 2nd ed. Cambridge: Cambridge University Press. Versnel, H.S. 1991. Beyond Cursing: The Appeal to Justice in Judicial Prayers. In C.A. Faraone and D. Obbink (eds.) Magika Hiera: Ancient Greek Magic and Religion. Oxford: Oxford University Press: 60-106.

Walker, D. 1988. The Roman Coins. In B. Cunliffe (ed.) The Temple of Sulis Minerva at Bath. Volume 2: The Finds from the Sacred Spring. Oxford: Oxford University Committee for Archaeology: 281-357.

Walton, P. 2008. The finds from the river. In H.E.M. Cool and D.J.P. Mason (eds.) Roman Piercebridge: Excavations by D.W. Harding and Peter Scott 1969-1981. The Architectural and Archaeological Society of Durham and Northumberland Research Report 7. Durham: The Architectural and Archaeological Society of Durham and Northumberland: 286-293.

Walton, P.J. 2012. Rethinking Roman Britain: Coinage and Archaeology. Collection Moneta 137. Wetteren: Moneta.

Wissowa, G. 1916-19. Interpretatio Romana: Römische Götter im Barbarenlande. Archiv für Religionswissenschaft 19:1-49.

Woolf, G. 1998. Becoming Roman: The Origins of Provincial Civilization in Gaul. Cambridge: Cambridge University Press. 